\title{
NUTRITIONAL ISSUES AND NUTRITION SUPPORT IN OLDER HOME CARE PATIENTS IN THE CITY OF ZAGREB
}

\author{
Darija Vranešić Bender ${ }^{1}$, Marta Kovačević ${ }^{2}$, Miro Hanževački ${ }^{3}$, Božena Vrabec ${ }^{3}$, \\ Vanesa Benković ${ }^{4}$, Viktor Domislović ${ }^{5}$ and Željko Krznarićc, ${ }^{2,5}$ \\ ${ }^{1}$ Zagreb University Hospital Center, Unit of Clinical Nutrition, Zagreb, Croatia; \\ ${ }^{2}$ Croatian Medical Association, Zagreb, Croatia; ${ }^{3}$ Zagreb-Zapad Health Centre, Zagreb, Croatia; \\ ${ }^{4}$ Croatian Society of Pharmacoeconomics and Health Economics, Zagreb, Croatia; \\ ${ }^{5}$ School of Medicine, University of Zagreb, Zagreb, Croatia
}

\begin{abstract}
SUMMARY - Population aging is a global demographic trend showing continuous growth and among its consequences is a rise in malnutrition that is characteristic for the elderly. The objective of this study was to evaluate nutritional status of elderly home care patients immediately after hospital discharge and to determine factors that affect nutritional status using questionnaires based on validated tools (NRS-2002, DETERMINE checklist) and basic medical history data. The study involved 76 elderly individuals (51.3\% of them older than 70 ) living in the City of Zagreb. The nutritional status assessment using the NRS-2002 tool showed that $57.6 \%$ of the subjects were at nutritional risk. The findings of the assessment by use of the DETERMINE tool were also unfavorable, indicating that $82.1 \%$ of persons older than 70 were categorized as being at a high nutritional risk, while $17.9 \%$ were at moderate risk. The DETERMINE checklist elements (illness; reduced intake of fruits, vegetables or dairy products; alcohol consumption; oral health problems; and weight loss) were linked to a higher NRS score. The mean number of hospital days in subjects at nutritional risk was 14.27 (the mean number in the Republic of Croatia is 8.56 days). Although the study involved a small number of subjects, the results showed a substantial presence of malnutrition among the elderly. A timely intervention by the healthcare system and training of healthcare personnel can be a step towards achieving a better nutritional status.
\end{abstract}

Key words: Nutritional status; Nutrition assessment; Elderly person; Malnutrition; Surveys and questionnaires; Home care services

\section{Introduction}

The global population is experiencing a negative trend of continuous aging, which is accompanied by growing needs for advances in healthcare for the elderly. The healthcare sector is continuously facing new challenges in providing this vulnerable population with timely care and enabling them to achieve better quality of life ${ }^{1}$. The assessment of the nutritional status

Correspondence to: Asst. Prof. Darija Vranešić Bender, BSc, PhD, Zagreb University Hospital Center, Unit of Clinical Nutrition, Kišpatićeva 12, HR-10000 Zagreb, Croatia

E-mail: dvranesi@kbc-zagreb.hr

Received October 11, 2017, accepted November 24, 2017 of the elderly is a topic of scientific research that is being studied worldwide with increasing frequency and using various validated methods of screening and assessment. An appropriate approach to nutritional status assessment is a prerequisite for establishing potential measures for addressing the issue of the prevalence of high nutritional risk in the elderly. The costs of healthcare for the elderly are higher than the costs for the general population, since the elderly are more likely to suffer from chronic noninfectious and malignant diseases. Furthermore, the elderly are more likely to be hospitalized and their length of stay in the hospital is longer than for the general population, which also increases treatment costs. The advancement of health- 
care management for the elderly is extremely important, and the objective is to design appropriate healthcare standards within the scope of primary, secondary and tertiary prevention programs $s^{2,3}$. Malnutrition is a frequent occurrence in the elderly population, especially in persons of low socioeconomic status. Moreover, malnutrition in the elderly is a public health issue influenced by numerous factors such as physiological changes, social and economic parameters. Declining oral health, loss of the sense of taste, dysphagia, diarrhea, depression, dementia, treatment with drugs, and other associated diseases increase the risk of malnutrition in the elderly ${ }^{4}$. Malnutrition is characterized by a protein-energy deficit that causes various changes in the composition and function of certain body parts, such as a weakened muscle function, reduced bone mineral density, immune system disorders, anemia, limited cognitive function, delayed wound healing, prolonged postoperative recovery, and an increased risk of hospital readmission and mortality. Furthermore, social factors such as poverty, loneliness, and a low level of education can reflect in food availability and, consequently, the nutritional status. The data available in scientific publications show that the prevalence of malnutrition is $15 \%$ in persons who live at home, $23 \%$ to $62 \%$ in hospitalized persons, and $85 \%$ in persons who live in nursing homes ${ }^{5}$.

The objective of this study was to evaluate the nutritional status of elderly home care patients after hospital discharge and to identify the factors that affect the poor nutritional status, such as diseases and psychosocial factors. Furthermore, the objective was to identify the type of nutritional support provided during previous hospitalizations, as well as the relation between the type of nutritional support and nutritional status or the length of hospital stay.

\section{Subjects and Methods}

A random sample of 76 subjects from the City of Zagreb were included in this epidemiological field study. The conditions to participate in the study were met by all persons older than 65 , immediately after hospitalization, living at home. Subject recruitment was conducted with the assistance of family doctors who had issued orders to visiting nurses to make home visits to elderly persons upon hospital discharge. The subjects were enrolled in the study from November
2015 to April 2016. The study was conducted with the aid of a questionnaire that was drawn up by using two validated instruments, the Nutritional Risk Screening 2002 (NRS-2002) ${ }^{6}$ and the DETERMINE checklist ${ }^{7}$, along with the basic medical history data. Nutritional risk assessment was conducted using a validated NRS2002 questionnaire. If the total score was three or higher, the patient was deemed to be at nutritional risk and nutritional support had to be implemented. The DETERMINE checklist was used for persons older than 70 in order to identify the reasons for the poor nutritional status of the subjects. The questionnaire consists of ten items on illness; oral health problems; consumption of certain food groups, alcohol, and medications; sufficient means for purchasing food; involuntary weight loss; and eating habits. A total score of 0 to 2 points indicates good nutritional health, 3 to 5 points indicate a moderate nutritional risk, and 6 or more points indicate a high nutritional risk. The basic medical history data (length of hospital stay and type of nutritional support) were obtained from available medical records.

Statistical analysis included correlation test and Student's t-test for measuring differences between two independent groups, with a p-value under 0.05 (twotailed test) representing the level of statistical significance. Statistical data processing was performed using SPSS software, version 23 (IBM Inc., USA).

\section{Results}

A total of 76 subjects older than 65 were included in the study. Of these subjects, $48.7 \%$ were younger than 70 , while $51.3 \%$ of the study population was older than 70 . According to the medical history data on the prevalence of various diseases, cardiovascular diseases were most prevalent (37.3\%), followed by malignant diseases (26.7\%). Diabetes was the third most prevalent disease in the study sample (22.7\%). Gastrointestinal tract diseases that directly affect the intake of food and therefore increase the risk of malnutrition were present in $18.7 \%$ of the study population. The results of the study showed that $10.7 \%$ of the subjects suffered a bone fracture, with femoral fractures accounting for $50 \%$ of these cases.

The level of nutrition of subjects in various categories based on the body mass index (BMI) is shown in Table 1 . The level of nutrition of the study population 
older than 70 was different from the population aged $<70$. A total of $38.9 \%$ of subjects older than 70 were classified as severely malnourished, and $16.7 \%$ of sub-

Table 1. Nutritional status according to body mass index (BMI)

\begin{tabular}{|l|l|l|l|l|}
\hline \multirow{2}{*}{} & \multicolumn{4}{|c|}{ Age of subjects (yrs) } \\
\cline { 2 - 5 } & $<70$ & \multicolumn{3}{|c|}{$\geq 70$} \\
\hline BMI category & $\begin{array}{l}\text { BMI } \\
\left(\mathrm{kg} / \mathrm{m}^{2}\right)\end{array}$ & $\%$ & $\begin{array}{l}\text { BMI } \\
\left(\mathrm{kg} / \mathrm{m}^{2}\right)\end{array}$ & $\%$ \\
\hline $\begin{array}{l}\text { Severe } \\
\text { malnutrition }\end{array}$ & $<18.5$ & 5.4 & $<20.0$ & 38.9 \\
\hline $\begin{array}{l}\text { Potential } \\
\text { malnutrition }\end{array}$ & $18.5-19.9$ & 2.7 & $20.0-21.9$ & 16.7 \\
\hline $\begin{array}{l}\text { Weight within } \\
\text { normal range }\end{array}$ & $20.0-24.9$ & 45.9 & $22.0-26.9$ & 27.8 \\
\hline Overweight & $25.0-29.9$ & 32.4 & $27.0-31.9$ & 16.7 \\
\hline Obesity class I & $30.0-34.9$ & 10.8 & $32.0-36.9$ & 0.0 \\
\hline Obesity class II & $35.0-39.9$ & 0.0 & $37.0-41.9$ & 0.0 \\
\hline Obesity class III & $40.0-50.0$ & 2.7 & $42.0-52.0$ & 0.0 \\
\hline
\end{tabular}

jects were classified as potentially malnourished. The weight of approximately $28 \%$ of subjects was within the normal range, and $16.7 \%$ of subjects were overweight. Obesity class I, II, and III was not recorded in this population. A higher percentage of subjects whose weight was within the normal range and overweight subjects fell within the category of younger than 70 .

The findings of the assessment conducted using the NRS-2002 tool indicated that $57.6 \%$ of the study population had a NRS score $\geq 3$ which, in turn, indicates the presence of nutritional risk. Less than half of the population (42.4\%) had an NRS score $<3$, and therefore those persons were not at nutritional risk. A statistically significant correlation between the NRS score and BMI was established using the bivariate correlation test. There was a moderate negative correlation, i.e. the valid hypothesis is that the lower the BMI, the higher is the NRS score $(r=-0.251, n=72, p<0.05)$.

The nutritional health assessment by using the DETERMINE checklist tool was conducted in 39 persons older than 70 . In $82.1 \%$ of this population, the total

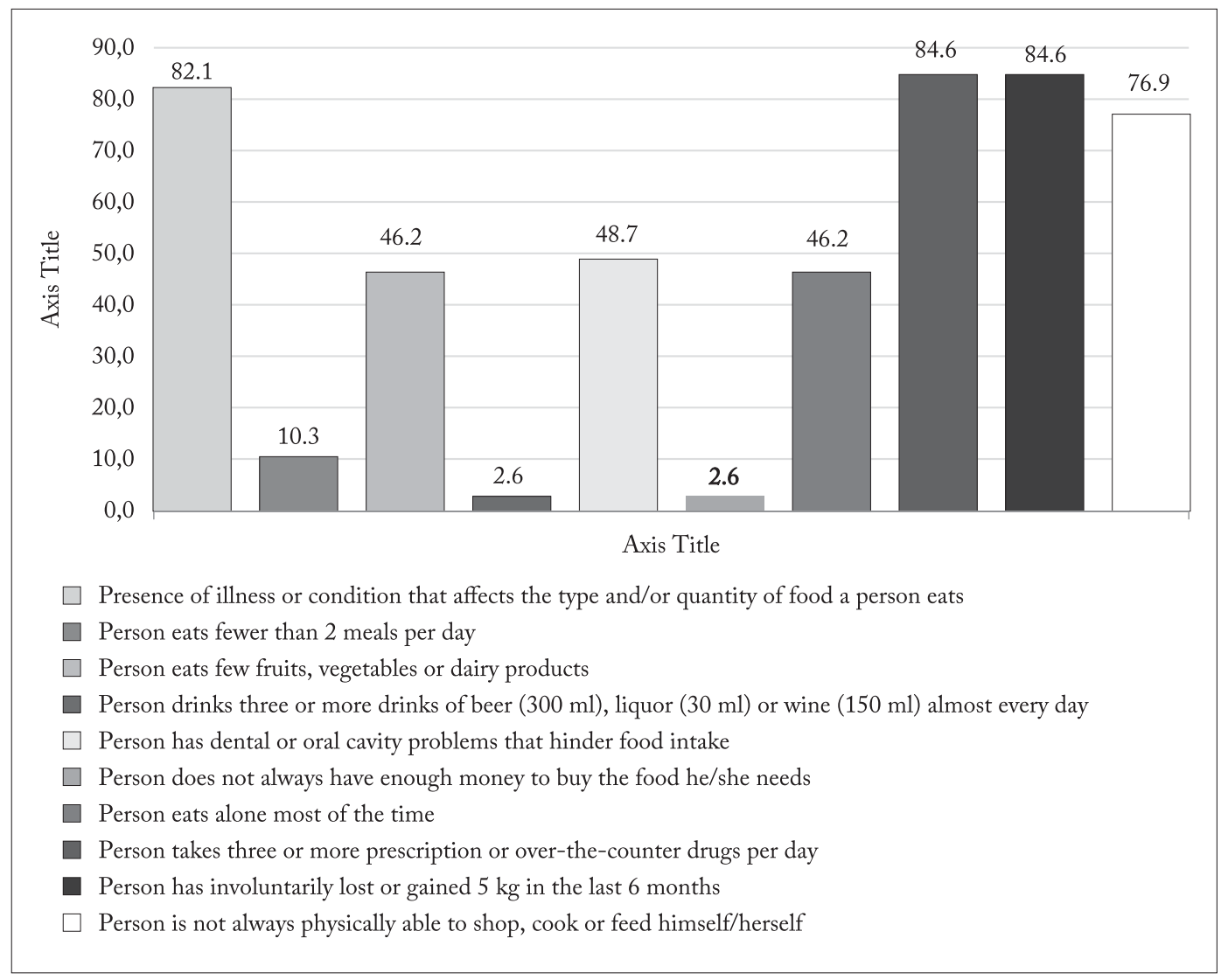

Fig. 1. Results of analysis according to DETERMINE checklist categories. 
Table 2. Statistically significant DETERMINE checklist elements that are related to bigh NRS score

\begin{tabular}{|l|l|l|l|l|l|}
\hline DETERMINE checklist element & $\begin{array}{l}\text { Presence } \\
\text { of element }\end{array}$ & $\mathrm{n}$ & $\mathrm{NRS}(\bar{x} \pm \mathrm{s})$ & $\mathrm{t}$ & $\mathrm{p}$ \\
\hline $\begin{array}{l}\text { Presence of illness or condition that affects the type } \\
\text { and/or quantity of food a person eats }\end{array}$ & $\begin{array}{l}\text { No } \\
\text { Yes }\end{array}$ & $\begin{array}{l}28 \\
46\end{array}$ & $\begin{array}{l}1.85 \pm 1.82 \\
2.74 \pm 1.77\end{array}$ & -2.06 & $\mathrm{p}<0.05$ \\
\hline The person eats few fruits, vegetables or dairy products & $\begin{array}{l}\text { No } \\
\text { Yes }\end{array}$ & $\begin{array}{l}53 \\
22\end{array}$ & $\begin{array}{l}2.06 \pm 1.81 \\
3.27 \pm 1.55\end{array}$ & -2.75 & $\mathrm{p}<0.01$ \\
\hline $\begin{array}{l}\text { The person drinks } 3 \text { or more drinks of beer }(300 \mathrm{~mL}), \\
\text { liquor }(30 \mathrm{~mL} \text { ) or wine }(150 \mathrm{~mL}) \text { almost every day }\end{array}$ & $\begin{array}{l}\text { Nes } \\
\text { Ye }\end{array}$ & $\begin{array}{l}2.34 \pm 1.79 \\
5.00 \pm 0.00\end{array}$ & -12.69 & $\mathrm{p}<0.001$ \\
\hline $\begin{array}{l}\text { The person has dental or oral cavity problems } \\
\text { that hinder food intake }\end{array}$ & $\begin{array}{l}\text { No } \\
\text { Yes }\end{array}$ & $\begin{array}{l}56 \\
19\end{array}$ & $\begin{array}{l}2.16 \pm 1.90 \\
3.16 \pm 1.30\end{array}$ & -2.54 & $\mathrm{p}<0.05$ \\
\hline $\begin{array}{l}\text { The person has involuntarily lost or gained } 5 \mathrm{~kg} \\
\text { in the last } 6 \text { months }\end{array}$ & $\begin{array}{l}\text { No } \\
\text { Yes }\end{array}$ & 33 & $\begin{array}{l}1.42 \pm 1.58 \\
3.19 \pm 1.61\end{array}$ & -4.76 & $\mathrm{p}<0.001$ \\
\hline
\end{tabular}

$\mathrm{n}=$ number of subjects; NRS $(\bar{x} \pm \mathrm{s})=$ Nutritional Risk Screening (arithmetic mean \pm standard deviation); $\mathrm{t}=\mathrm{t}$-value; $\mathrm{p}=\mathrm{p}$-value

score of all DETERMINE checklist elements was $\geq 6$, i.e. those persons were at a high nutritional risk. A total of $17.9 \%$ of the study population were at a moderate nutritional risk (score 3-5). None of the persons was found to be in good nutritional health. The analysis according to DETERMINE checklist categories is shown in Figure 1. A fact to be highlighted from the findings is that $84.6 \%$ of persons took three or more prescription or over-the-counter (OTC) drugs per day. A total of $82.1 \%$ of subjects suffered from an illness or condition that affects food consumption, and $76.9 \%$ of subjects were physically unable to shop for food and cook, which is also reflected in food consumption. The percentage of patients with substantial body mass oscillation in the last 6 months was $84.6 \%$. The statistically significant findings of the correlation between individual DETERMINE checklist elements and the NRS score are shown in Table 2. The findings indicated that subjects in whom the aforementioned DETERMINE checklist elements were marked had a statistically significant correlation with a higher NRS score compared to subjects in whom those elements were not marked. These elements are illness; reduced intake of fruits, vegetables or dairy products; alcohol consumption; oral health problems; and weight loss.

The mean number of hospital days in subjects who were not at nutritional risk (NRS $<3$ ) was 12.85 , while the number of hospital days was higher in subjects who were at nutritional risk (NRS $\geq 3$ ), amounting to 14.27. No statistically significant difference was found in the length of hospital stay and the NRS score.
The types of nutritional support provided during hospitalization were divided into four basic categories: nutritional support, dietary advice, enteral nutrition, and parenteral nutrition. Enteral nutrition (35.7\%) and parenteral nutrition (41.1\%) were the most prevalent types of nutritional support provided to the study sample. No nutritional support was provided to $26.8 \%$ of subjects during their hospitalization. Testing the correlation between hospital length of stay and the type of nutritional support during hospitalization (enteral, parenteral, dietary advice, and no support) yielded no statistically significant difference. Correlation analysis between the type of nutritional support during last hospitalization and the NRS score showed a statistically significant difference indicating a strong correlation, i.e. the higher the NRS score, the higher was the level of nutritional support $(r=0.502, n=56$, $\mathrm{p}<0.01)$.

\section{Discussion}

The nutritional status of the elderly is affected by numerous changes characteristic of this phase of life, such as physiological, socioeconomic and psychological changes. Nutritional status assessment is based on anthropometric parameters and nutritional risk assessment tools ${ }^{8}$. The Mini Nutritional Assessment (MNA) is the most frequently used nutritional status assessment tool. MNA is a tool intended for use by trained healthcare professionals, and it has been used in a vast number of studies ${ }^{9}$. Furthermore, most studies related 
to nutritional status assessment in the elderly have been conducted on samples of institutionalized persons, which usually includes hospitalized patients and nursing home residents, while fewer studies pertain to the elderly who independently live at home. The objective of this study was to determine the nutritional status of elderly persons receiving home care after hospital discharge and to identify the factors that affect their nutritional status in order to lay the foundation for further development of healthcare and improvements of healthcare in this population, which has been insufficiently studied until now. Since visiting nurses were involved in the data gathering process, a questionnaire drawn up on the basis of validated tools (NRS-2002 and DETERMINE checklist) was used to ensure simplicity and ease of use ${ }^{10}$.

According to the medical history data obtained, the findings on the prevalence of the most frequent chronic illnesses correspond to other data available in scientific publications. Cardiovascular diseases that cause $47 \%$ of deaths in Europe and $40 \%$ of deaths in European Union Member States are the most prevalent, and it is estimated that 4 million people in $\mathrm{Eu}^{-}$ rope or 1.9 million people in the European Union die every year from cardiovascular diseases ${ }^{11}$. Malignant diseases are the second most prevalent cause of morbidity and mortality in the world ${ }^{12}$. Diabetes mellitus was the third most prevalent disease in the study sample. Chentli et al. state that, on average, $20 \%$ of elderly people suffer from diabetes mellitus, and that another $20 \%$ suffer from the disease but have not been diagnosed $^{13}$. Data on this elderly population show that $50 \%$ of all bone fractures are femoral fractures.

Body mass index is a simple tool that is used to assess nutritional status in adults. This population shows a contrast in BMI categories in patients older than 70, with a significantly higher percentage of subjects who are severely malnourished and potentially malnourished. The results are in line with the fact that elderly people are at a higher risk of malnourishment due to physiological and socioeconomic reasons, as well as comorbidity, and the fact that the range of BMI values is different for people younger and older than $70^{14}$.

The results of this study, obtained by assessment using the NRS-2002 tool, indicated that nutritional risk was present in $57.6 \%$ of subjects. Rist et al. conducted a similar study using the MNA tool on a sample of 235 Australians older than 65 who were receiv- ing home care. According to their findings, $57.4 \%$ of subjects were not at risk of malnutrition, $34.5 \%$ of subjects were at risk, and malnutrition was identified in only $8.1 \%$ of subjects ${ }^{15}$. If we compare the aforementioned findings, we can conclude that the findings obtained from the Australian population are more favorable than this Croatian sample. Despite that fact, the authors believe that such statistics are troubling, and that the issue of nutritional risk in the elderly should be addressed by implementing certain nutritional interventions, especially in the population that is at an increased nutritional risk.

This study showed the BMI decrease to be followed by an increase in the NRS score, which is in line with the results obtained by other studies. Saka et al. conducted a study on the impact of nutritional status on serum prealbumin, whereby they also took into consideration other parameters such as BMI and length of hospital stay. When assessing nutritional status, they used the NRS-2002 tool and found that 71\% of subjects older than 65 were at nutritional risk. Furthermore, persons with a high NRS score were found to have lower BMI values that were of statistical significance ${ }^{16}$.

According to the DETERMINE checklist results, the percentage of persons at high nutritional risk was troubling (82.1\%). Persons at high nutritional risk (17.9\%) should request help from the competent family doctor, and persons at moderate nutritional risk should be instructed on how to change their lifestyle and dietary habits, and they should be reassessed after three months. A major European study within the scope of the Food in Later Life project was conducted over a two-year period in eight European countries (Denmark, Germany, Italy, Poland, Portugal, Spain, Sweden, and the United Kingdom). The objective of the study was to identify the nutritional risk of the $\mathrm{Eu}-$ ropean elderly who live at home, and the assessment was conducted by using the DETERMINE checklist tool. Nearly half of the population $(47.3 \%)$ were in good nutritional health, one-quarter $(27.3 \%)$ of the population were at moderate nutritional risk, while the lowest percentage $(25.4 \%)$ of the population were at high nutritional risk $^{8}$. One of the principal causes of malnutrition in developed European countries is chronic or acute illness. Illness is actually a series of inflammatory processes in the body that affect the metabolism, appetite, absorption and efficiency of nutri- 
ents ${ }^{17}$. The results of the analysis conducted on the study sample showed the presence of an illness or a condition affecting food consumption in $82.1 \%$ of subjects (Fig. 1). One-third (30.6\%) of elderly persons that participated in the study by Morais et al. suffer from an illness affecting the type and quantity of food they consume ${ }^{8}$. Differences between the results of the study by Morais et al. and our study could be explained by difference in the populations observed. In their study, Morais et al. observed a population of elderly subjects $^{8}$, whereas we observed a population of elderly subjects immediately after hospital discharge, which explains the high percentage of persons at moderate and high nutritional risk in our population, and a high percentage of persons in whom illness affected the type and quantity of food they consumed.

In addition to their primary diagnosis, the elderly often have several comorbid diagnoses and therefore take a greater quantity of different drugs. Polypragmasy is characteristic of the elderly ${ }^{18}$, and according to the DETERMINE checklist results shown in Figure $1,84.6 \%$ of subjects were taking three or more prescription or OTC drugs per day. The results of the study by Morais et al. conducted on 664 elderly people in Europe show that $50.2 \%$ of subjects were taking three or more drugs per day ${ }^{8}$. Drugs can cause disruption in food consumption and directly or indirectly affect numerous metabolic pathways, which ultimately affects the nutritional status. More than 250 drugs can affect the intake, absorption, metabolism, and excretion of nutrients ${ }^{18}$.

Illness often affects mobility, and therefore elderly people are not always physically able to shop for food and cook, which also reflects in food consumption. Such cases feature in the study population; as much as $76.9 \%$ of subjects were not physically able to perform the aforementioned activities. Similar results were shown in a previous study; malnutrition was present in the $63.8 \%$ of the study population, who were unable to independently perform activities such as shopping for food and cooking 5 .

Major studies such as the National Diet and Nutrition Survey (NDNS) and the National Health and Nutritional Examination Survey (NHANES) found poor dental status to pose a substantial risk of malnutrition ${ }^{19}$. The present study confirmed the aforementioned theory since $48.7 \%$ of subjects experienced problems with dentures and oral cavity, and were found to have a statistically significant tendency towards a high NRS score. Poor nutritional status is a result of a decreased intake of food that requires chewing due to its firm texture, for example meat, fruit and vegetables $^{19}$.

A total of $46.2 \%$ of subjects experienced loneliness (Fig. 1); Morais et al. report on an almost identical result, i.e. $47.5 \%$ of subjects were eating alone most of the time ${ }^{8}$. The SOLINUT study has found that people who eat alone have a decreased appetite, and therefore a reduced nutritional intake ${ }^{20}$. A reduced consumption of fruit, vegetables and dairy products has a direct effect on poor nutritional status and, according to the results obtained, it was present in $46.2 \%$ of subjects (Fig. 1). Johnson et al. studied fruit and vegetable consumption on a sample of 445 persons older than 65 . Their results have shown that $37 \%$ of people who live in urban areas and $51 \%$ of people from rural areas do not consume the recommended five portions of fruit and vegetables per day. As potential reasons, they cite lower social status than that of the general population, reduced appetite and sense of taste, and reduced physical ability to prepare vegetables or meals ${ }^{21}$. The activity of the enzyme lactase becomes reduced over years, which leads to the onset of lactose intolerance. People experience difficulties in tolerating milk and dairy products, which results in the feeling of weakness, nausea, etc. ${ }^{22}$. Lactose intolerance is a potential explanation for the reduced intake of dairy products in the study sample.

The presented findings of the correlation between certain DETERMINE checklist elements and the NRS score indicated that subjects in whom the aforementioned elements were marked had a statistically significantly higher nutritional risk than the subjects in whom those elements were not marked (Table 2). A study by Pohlhausen et al. involved 353 homecare patients older than 65 , showing that $31 \%$ of men and $36 \%$ of women experienced problems with chewing, and $33 \%$ of men and $26 \%$ of women experienced problems with swallowing. A statistically significant correlation was found between the problems with swallowing or chewing and a weakened nutritional status ${ }^{23}$. Such results are in line with the results obtained in our study, indicating that people with declining dental or oral cavity health showed a statistically significantly higher tendency towards high NRS score. Moreover, 
people who eat few fruits and vegetables are at a substantially higher nutritional risk. In the study by $\mathrm{Mo}^{-}$ rais et al., $16.5 \%$ of subjects ate few fruits, vegetables and dairy products, and they were exhibiting higher nutritional risk $^{8}$. Such results indicate that better approach should be developed for serving fruit and vegetables to the elderly in order to reduce, at least partially, the potential nutritional risk. Great oscillations in body mass, especially in the elderly, can be an indicator of poor nutritional status ${ }^{8}$. People who frequently consume alcohol usually have a lower food intake, and thereby a reduced intake of carbohydrates, proteins and vitamins. Furthermore, the metabolism of alcohol affects the absorption and efficiency of nutrients, which is reflected as a high nutritional risk ${ }^{24}$. People who drink 3 or more drinks of beer $(300 \mathrm{~mL})$, liquor $(30 \mathrm{~mL})$ or wine $(150 \mathrm{~mL})$ almost every day have a tendency towards a high NRS score or nutritional risk.

A prompt nutritional status assessment or identification of nutritional risk can contribute to a timely and proper nutritional intervention, which reduces the length of hospital stay and ultimately results in lower treatment $\operatorname{costs}^{25}$. Martins et al. conducted a study on 207 subjects older than 65 with the objective to assess nutritional status of patients using the MST, MNA, SGA and NRS-2002 tools, and to establish whether there is a correlation with length of hospital stay ${ }^{26}$. The findings showed that there was a statistically significant correlation between patients classified as being at nutritional risk according to their NRS score and an extended stay in hospital. An extended stay was defined as one that lasted for more than 8 hospital days. A study with a similar objective was conducted by Gökcan et al. on a sample of 2566 subjects $^{25}$. The findings showed that there was a statistically significant correlation between the length of hospital stay and high nutritional risk. A little less than half of the patients (41.6\%) at high nutritional risk (NRS $\geq 3$ ) had a statistically significantly extended hospital stay. The results of this study did not show a statistically significant correlation between the length of hospital stay and the NRS score contradict the results of other studies. A substantial difference in sample size in the studies by Martins et al. ${ }^{26}$ and Gökcan et al. ${ }^{25}$ compared to the present study may account for such results.

Our study showed no statistically significant difference between the length of hospital stay and the type of nutritional support. Furthermore, there was no statistically significant difference between the length of hospital stay and the NRS score. Analysis of the correlation between the type of nutritional support during the last hospitalization and the NRS score revealed that the elderly who were at higher nutritional risk received a higher level of nutritional support. Results of a study conducted in China on 5034 patients, $19.2 \%$ of whom were at nutritional risk (NRS $\geq 3$ ) at the time of admission to the hospital, showed the degree of complications to be lower and the length of hospital stay significantly shorter in persons who received nutritional support in comparison to persons who received no nutritional support $(20.9 \% \text { vs. } 30.0 \%, \mathrm{p}<0.05)^{27}$. The difference in results compared to our study can be explained by difference in the sample size.

The mean number of hospital days in subjects who were not at nutritional risk (NRS $<3$ ) was 12.85 , while in subjects who were at nutritional risk (NRS $\geq 3$ ) the number of hospital days was 14.27. A report on the activities of hospitals in Croatia in 2015 shows that the total mean length of stay in the hospital was 8.56 days, which is significantly lower than our data ${ }^{28}$. One of the explanations for this difference is the advanced age of our sample patients in whom the percentage of chronic illnesses and related complications was higher than in the general population.

In conclusion, assessment of the nutritional status of subjects between 65 and 70 years of age using their BMI showed that the weight of most of the subjects was either within the normal range or they were overweight, while only $5.4 \%$ of subjects were malnourished. On the other hand, the majority of the subjects older than 70 were malnourished or at risk of malnourishment. These results contribute to similar results showing that aging increases the risk of malnourishment. The nutritional status assessment conducted using the NRS-2002 tool showed that $57.6 \%$ of subjects were at nutritional risk. The results obtained by assessment using the DETERMINE checklist were also unfavorable, with $82.1 \%$ of subjects older than 70 being at high nutritional risk and $17.9 \%$ being at moderate risk. Such a high percentage of the population at nutritional risk indicates that more attention should be devoted to nutrition and nutritional support within the healthcare system. Subjects who suffer from an illness or a condition that affects the quantity of food they consume; who eat few fruits, vegetables or dairy 
products; drink three or more drinks of beer, liquor or wine almost every day; who suffer from dental problems; or have involuntarily lost/gained $5 \mathrm{~kg}$ in the last 6 months have a statistically higher tendency towards nutritional risk. A moderate negative correlation between BMI and NRS score means that subjects with lower BMI are at higher nutritional risk. A small number of subjects were included in this study. Additional and more comprehensive studies are needed in order to establish a realistic overview of the status of the population. However, these results are sufficient to indicate that the issue of malnutrition is present among the elderly. A timely intervention by the healthcare system and training of healthcare personnel can be a step towards achieving better results.

\section{References}

1. Agarwal E, Miller M, Yaxley A, Isenring E. Malnutrition in the elderly: a narrative review. Maturitas. 2013;76(4):296-302, http://dx.doi.org/10.1016/j.maturitas.2013.07.013

2. Murgić J, Jukić T, Tomek-Roksandić S, Ljubičić M, Kusić Z. The ageing of Croatian population. Coll Antropol. 2009;33 (2)701-5.

3. Zavoreo I, Madžar Z, Demarin V, Bašić Kes V. Vascular cognitive impairment in diabetes mellitus: are prevention and treatment effective? Acta Clin Croat. 2014 Sep;53(3):326-33.

4. Poulia KA, Yannakoulia M, Karageorgou D, Gamaletsou M, Panagiotakos DB, Sipas NV, et al. Evaluation of the efficacy of six nutritional screening tools to predict malnutrition in the elderly. Clin Nutr. 2012 Jun;31(3):378-85, http://dx.doi.org/10.1016/j.clnu.2011.11.017

5. Donini LM, Scardella P, Piombo L, Neri B, Asprino R, Proietti AR, et al. Malnutrition in elderly: social and economic determinants. J Nutr Health Aging. 2013 Jan;17(1):9-15, http://dx.doi.org/10.1007/s12603-012-0374-8

6. Kondrup J, Allison SP, Elia M, Vellas B, Plauth M. ESPEN Guildelines for Nutrition Screening. Clin Nutr. 2003 Aug; 22(4):415-21.

7. De Groot LC, Beck AM, Schroll M, van Staveren WA. Evaluating the DETERMINE Your Nutritional Health Checklist and the Mini Nutritional Assessment as tools to identify nutritional problems in elderly Europeans. Eur J Clin Nutr. 1998 Dec;52(12):877-83.

8. Morais C, Oliveira B, Afonso C, Lumbers M, Raats M, Almedia MD. Nutritional risk of European elderly. Eur J Clin Nutr. 2013 Nov;67(11):1215-9, http://dx.doi.org/10.1038/ejcn.2013.175

9. Vellas B, Guigoz Y, Garry PJ, Nourhashemi F, Bennahum D, Lauque S, et al. The Mini Nutritional Assessment (MNA) and its use in grading the nutritional state of elderly patients. Nutrition. 1999 Feb;15(2):116-22.
10. Benceković Ž, Benko I, Režek B, Grgas-Bile C. The role and promotion of nursing. Acta Clin Croat. 2016 Jun;55(2):271-8.

11. esccardio.org [Internet] European Cardiovascular Disease Statistics. EHN - European Heart Network; c2012 [cited 2016 June 27] Available from: http://www.escardio.org/static_file/ Escardio/Press-media/press-releases/2013/EU-cardiovascular-disease-statistics-2012.pdf

12. Štimac D, Krznarić Z, Vranešić Bender D, Obrovac Glišić M. Dijetoterapija i klinička prehrana. Zagreb: Medicinska naklada; 2014. p. 151. (in Croatian)

13. Chentli F, Azzoug S, Mahgoun S. Diabetes mellitus in elderly. Indian J Endocrinol Metab. 2015 Nov-Dec;19(6):744-52, http://dx.doi.org/10.4103/2230-8210.167553

14. Cederholm T, Bosaeus I, Barazzoni R, Bauer J, Van Gossum A, Klek S, et al. Diagnostic criteria for malnutrition - an ESPEN Consensus Statement. Clin Nutr. 2015 Jun;34(3):335-40, http://dx.doi.org/10.1016/j.clnu.2015.03.001

15. Rist G, Miles G, Karimi L. The presence of malnutrition in community - living older adults receiving home nursing services. Nutr Diet. 2012 Feb;46-50, http://dx.doi.org/10.1111/j.1747-0080.2011.01572.x

16. Saka B, Ozturk GB, Uzun S, Erten N, Genc S, Karan MA, et al. Nutritional risk in hospitalized patients: impact of nutritional status on serum prealbumin. Rev Nutr. 2011;24(1): 89-98, http://dx.doi.org/10.1590/S1415-52732011000100009

17. Norman K, Pichard C, Lochs H, Pirlich M. Prognostic impact of disease-related malnutrition. Clin Nutr. 2008 Feb;27(1): 5-15, http://dx.doi.org/10.1016/j.clnu.2007.10.007

18. Zadak Z, Hyspler R, Ticha A, Vlcek J. Polypharmacy and malnutrition. Curr Opin Clin Nutr Metab Care. 2013 Jan;16(1): 50-5, http://dx.doi.org/10.1097/MCO.0b013e32835b612e

19. Gil-Montoya JA, Ponce G, Sanchez Lara I, Barrios R, Llodra JC, Bravo M. Association of the oral health impact profile with malnutrition risk in Spanish elderly. Arch Gerontol Geriatr. 2013 Nov-Dec;57(3):398-402, http://dx.doi.org/10.1016/j.archger.2013.05.002

20. Ferry M, Sidobre B, Lambertin A, Barberger-Gateau P. The SOLINUT study: analysis of the interaction between nutrition and loneliness in person aged over 70 years. J Nutr Health Aging. 2005;9(4):261-8.

21. Johnson AE, Donkin AJM, Morgan K, Neale RJ, Page RM, Silburn RL. Fruit and vegetable consumption in later life. Age Ageing. 1998 Nov;27(6):723-8.

22. Montalto M, Curigliano V, Santoro L, Vastola M, Cammarota G, Manna R, et al. Management and treatment of lactose malabsorption. World J Gastroenterol. 2006;12(2):187-91.

23. Pohlhausen S, Uhlig K, Kiesswetter E, Diekmann R, Heseker H, Volkert D, et al. Energy and protein intake, anthropometrics, and disease burden in elderly home care receivers - a cross sectional study in Germany. J Nutr Health Aging. 2016 Mar;20(3):361-8, http://dx.doi.org/10.1007/s12603-015-0586-9

24. pubs.niaaa.nih.gov [Internet] National Institute on Alcohol Abuse and Alcoholism; c2004 [cited 2016 Sept 1]. Available from: http://pubs.niaaa.nih.gov/publications/arh27-3/220-231.htm 
25. Gökcan H, Selçuk H, Töre E, Gülseren P, Cambaz H, Sarıtaş S, et al. The Nutritional Risk Screening 2002 tool for detecting malnutrition risk in hospitalised patients: perspective from developing country. Turk J Gastroenterol. 2014;25(6):718-23, http://dx.doi.org/10.5152/tjg.2014.6651

26. Martins, CP, Correia JR, Freitas do Amaral TF. Undernutrition risk screening and length of stay of hospitalized elderly. J Nutr Elder. 2005;25(2):5-21.

27. Jia ZY, Yang J, Tong DN, Peng JY, Zhang ZW, Liu WJ, et al. Screening of nutritional risk and nutritional support in general surgery patients: a survey from Shangai, China. Int Surg. 2015;100(5):841-8,

http://dx.doi.org/10.9738/INTSURG-D-14-00245.1

28. www.hzjz.hr [Internet] Rad bolnica u Hrvatskoj 2015. godine; c2016 [cited 2017 Nov 11]. Available from: https://www. hzjz.hr/wp-content/uploads/2016/08/Rad_bolnica_2015.pdf. (in Croatian)

Sažetak

\section{NUTRITIVNI PROBLEMI I NUTRITIVNA POTPORA U BOLESNIKA STARIJE DOBI NA KUĆNOJ NJEZI U GRADU ZAGREBU}

\section{Vranešić Bender, M. Kovačević, M. Hanževački, B. Vrabec, V. Benković, V. Domislović i Ž. Krznarić}

Starenje stanovništva je globalni demografski trend u stalnom porastu, a time je u porastu i malnutricija karakteristična za osobe starije životne dobi. Cilj ovoga rada bio je procijeniti nutritivni status osoba starije životne dobi na kućnoj njezi neposredno nakon otpusta iz bolnice te utvrditi čimbenike koji utječu na nutritivni status. Korišten je upitnik sastavljen na temelju validiranih instrumenata (NRS-2002, upitnik DETERMINE) i osnovnih anamnestičkih podataka. Istraživanjem je obuhvaćeno 76 osoba starije životne dobi (51,3\% stariji od 70 godina) na području grada Zagreba. Procjenom nutritivnog statusa upitnikom NRS-2002 u 57,6\% ispitanika utvrđen je nutritivni rizik. Rezultati utvrđeni procjenom pomoću upitnika DETERMINE također su bili nepovoljni: $82,1 \%$ osoba starijih od 70 godina imalo je visok nutritivni rizik, dok ih je $17,9 \%$ imalo umjeren rizik. Elementi upitnika DETERMINE (prisutnost bolesti, smanjen unos voća, povrća ili mliječnih proizvoda, konzumacija alkoholnih pića, problemi s oralnim zdravljem i gubitak tjelesne mase) povezani su s višim rezultatom NRS. Prosječan broj dana hospitalizacije u ispitanika s nutritivnim rizikom bio je 14,27 dana (prosjek u Republici Hrvatskoj je 8,56 dana). Iako je istraživanjem obuhvaćen mali broj ispitanika, već i ovakvi rezultati ukazuju na to da je problem malnutricije u velikoj mjeri prisutan među osobama starije životne dobi. Pravodobna intervencija sustava zdravstvene zaštite i izobrazba zdravstvenog osoblja može biti korak prema postizanju boljeg nutritivnog statusa.

Ključne riječi: Prebrambeni status; Prehrana, procjena; Starija osoba; Malnutricija; Ankete i upitnici; Patronažna služba 